\title{
Studies on the Growth and Flowering Behavior of Different Mango (Mangifera indica L.) Genotypes
}

\author{
G. Indian ${ }^{\text {** }}$, Eslavathkhamdar Naik ${ }^{1}$, M. Deenavarman ${ }^{2}$, K. Jagathesan ${ }^{3}$ and T. Janani ${ }^{3}$ \\ ${ }^{1}$ Fruit science, Department of Fruit Crops, ${ }^{2}$ Floriculture and Landscaping, Department of \\ Floriculture and Medicinal Crops, ${ }^{3}$ Vegetable science, Department of Vegetable Crops, \\ HC\&RI (TNAU), Periyakulam, Tamilnadu, India \\ *Corresponding author
}

\section{A B S T R A C T}

\section{Keywords}

Mango,

Genotypes,

Growth,

Flowering

Article Info

Accepted:

18 May 2020

Available Online:

10 June 2020

\begin{abstract}
Growth and inflorescences characteristics of 30 mango genotypes were studied during the period of 2017 to 2018.The evaluation of new cultivars adaptation of mango (Mangifera indica L.) provides tools to assist and improve the mango production in different climatic conditions. The study was conducted to evaluate the phenological and reproductive development of different mango genotypes. The variables like total tree height, tree spread, tree girth, leaf length, leaf width, petiole length, Date of panicle emergence, panicle length, panicle width, number of male and perfect flowers, perfect flower percentage and sex ratio were recorded during the period of study. The average tree height $(8.36 \mathrm{~m})$, tree spread $(8.99 \mathrm{~m})$ and stem girth $(103.97 \mathrm{~cm})$ was found to be observed maximum in Sundar Langra. The maximum leaf length, leaf width and petiole length was observed significantly in Alphonso $(32.85 \mathrm{~cm})$, Sindhu $(10.24 \mathrm{~cm})$ and ArkaAruna $(6.28$ $\mathrm{cm}$ ) respectively. Results pertaining to panicle emergence suggest that Malpacharisi, Sendhuram, Arka Aruna and Imam pasandhad very early emergence of panicle (before January).The maximum percentage of perfect flowers per inflorescence was recorded significantly in Sothuparaivadumangai $(31.43 \%)$. Among the genotypes PKM 1exhibited significantly maximum sex ratio (hermaphrodite flowers to male flowers) (1:5.43). It is concluded that some genotypes like SundarLangra, ArkaAruna, Sendhuram and Alphonso were superior in most of the traits.
\end{abstract}

\section{Introduction}

Mango (Mangifera indica L.) is the most popular fruit crop in the orient particularly in India, where it is considered as the best choice among all indigenous fruits. It is a tropical fruit originated from Indo-Burma region and grown almost all part of the world. It is a majorfruit crop of India and occupies an area of 2.263 million hectares with an annual production of 19.68 million tonnes and the productivity is $8.71 \mathrm{MT} / \mathrm{hac}$. The export potential of India is 52761 MT of fresh and dried products of mango with the benefit cost of Rs.44,366 Lacs (APEDA, 2016-17). The area, production and productivity of mango in 
TamilNadu is 160.49 thousand hac, 1.157 million tonnes and $7.19 \mathrm{MT} / \mathrm{hac}$ (India stat 2016-17). Different cultivars of mango varied in their performance and these differences are governed by various genetic, cultural and environmental factors. The growth of the mango trees is usually given by cycles with short repetitions throughout the year and it is depending on the cultivar, climate conditions and management. The knowledge about the growth pattern of the mango trees is essential for establishing effective methods to handle the culture and it allows the phenotypic characteristics expressions of each genetic material. Among the mango trees phenophases, the flowering is a complex phenomenon as long as its duration and it may be extended earlier by natural conditions or artificial inductions, it depends on climatic conditions and previous crop productivity. The mango trees have higher productions in regions with cold and/or dry period preceding flowering, humid soil and maximum air temperature between $30{ }^{\circ} \mathrm{C}$ and $33{ }^{\circ} \mathrm{C}$ during the fruit development. Temperatures above 35 ${ }^{\circ} \mathrm{C}$ cause injury in plants and temperatures from $8{ }^{\circ} \mathrm{C}$ to $10^{\circ} \mathrm{C}$ during the cold period of the year may be regarded as the lower limit for the successful mango production. A temperature regime of $25{ }^{\circ} \mathrm{C}$ during the day and $15{ }^{\circ} \mathrm{C}$ during the night as prevails during this period was found to be the optimum for flower induction. Prior to flowering, farmers do not irrigate in order to enhance drought stress to support flower induction. The knowledge of the phenology of mango cultivars can be used for genetic breeding or even for cultivation in new planting areas and on the range of processes linked to agronomic management of the supply chain. Looking to above fact, it was realized to ascertain the performance of different cultivars of mango growing under the agro-climatic conditions of Tamilnadu for different phenological and reproductive development among mango cultivars. The information generated from this study will enable the effective utilization of mango genetic resources especially breeding programme for improvement of this crop.

\section{Materials and Methods}

The present investigation was conducted at Horticultural College and Research Institute (HC\&RI) of TamilNadu Agricultural University, Periyakulam, TamilNadu, during the period of 2017 and 2018. The experiment was carried out on thirtymango genotypes namely, Alphonso, Amarapali, ArkaAruna, ArkaPuneet, $\mathrm{Au}$ Rumani, Banganapalli, Duraipandi, Iswarya, Imam pasand,Javari, Komangai, Kovankachi, KundurPacharisi, KuruviNeelum, Mallika, Malpacharisi, Mohandhas, NathamPalamani, Neelum, P.K.Patti, Pedharasam, PKM 1, PKM 2, Ratna, Samba Kooja, Shajahan, Sendhuram, Sindhu, Sothuparai Vadumangai and Sundar Langra available at the experimental orchard of the Horticultural College and Research Institute (HC\&RI), Periyakulam. Plants of these mango genotypes were ten years old, healthy and free from diseases and pests. These plants were maintained under uniform cultural practices to ensure yield of quality fruits. Observations were made on vegetative and flowering characteristics like tree height, tree spread, Stem girth, Leaf length, Leaf width, panicle length and width, number of male and perfect flowers and Perfect flower per cent among the different mango genotypes. The collected data on different parameters were analyzed by using analysis of variance (ANOVA) based on randomized block design (RBD). The data's were recorded by following methods.

\section{Tree height (m)}

Tree height was measured with the help of bamboo and measuring tape from base as ground level to the apex of the tree and expressed in meters. 


\section{Stem girth $(\mathbf{c m})$}

The trunk girth was measured at $30 \mathrm{~cm}$ height from the ground level with the help of a measuring tape and expressed in centimeters.

\section{Tree spread (m)}

The tree spread was measured by measuring the canopy spread in East-West (E-W) and North-South (N-S) directions with the help of measuring tape. Average it and it was expressed in meter.

\section{Leaf length (cm)}

Average length of randomly selected 15 leaves from five shoots excluding petiole was taken from third and fourth positions from the tip of bearing shoot was recorded as leaf length and measured in centimeter.

\section{Leaf width (cm)}

Average width of randomly selected 15 leaves from five shoots was taken from third and fourth positions from the tip of bearing shoot were recorded as leaf width. The leaf width was measured in the upper, middle and lower portion of the leaf, averaged and expressed in centimeter.

\section{Petiole length $(\mathrm{cm})$}

Average length of petiole of randomly selected 15 leaves taken from third and fourth position from tip of the each bearing shoot was measured and expressed in centimeter.

\section{Percentage of perfect flowers per inflorescence}

The percentage of perfect flowers was calculated by using the following formula.
Number of perfect flowers per panicle

Total number of flowers per panicle $\mathrm{x} 100$

\section{Sex ratio (Perfect to male flowers)}

The ratio of male flowers to hermaphrodite flowers was calculated as follows. (keeping the perfect flowers as constant one).

Sex ratio $=$

Number of perfect flowers per panicle:

Number of perfect flowers per panicle

Numbermale flowers per panicle

\section{Results and Discussion}

\section{Tree growth parameters}

The height of tree is one of the most important quality parameters which reflect the growth and quality of mango tree. Among the genotypes, SundarLangra exhibited the maximum tree height $(8.36 \mathrm{~m})$, tree spread $(8.99 \mathrm{~m})$ and stem girth $(103.97 \mathrm{~cm})$. However, minimum tree height $(3.57 \mathrm{~m})$, tree spread $(3.35 \mathrm{~m})$ and stem girth $(25.13 \mathrm{~cm})$ were recorded in Samba Kooja, P.K. Patti and Javari respectively (Table 1 ). The variation in plant height among the different varieties could be due to the variation in genetic makeup under the present set of environmental and edaphic conditions. High variability in plant height amongst the mango varieties have also been determined by Chanana et al., (2005). This variation with respect to plant spread among the different cultivars may be due to spreading and intermediate spreading habit of the cultivar. Similar results have also been reported by Rymbai (2012). The variation in vegetative growth characters with respect to stem girth among mango varieties might be due to variation in genetic make-up. The more or less similar result has been reported by Srivastava et al., (1987). 


\section{Leaf growth parameters}

The maximum leaf length $(32.85 \mathrm{~cm})$ leaf width $(10.24 \mathrm{~cm})$ and petiole length $(6.28 \mathrm{~cm})$ was observed significantly in Alphonso, Sindhu and ArkaAruna, respectively, while the minimum leaf length $(15.88 \mathrm{~cm})$ and leaf width $(2.64 \mathrm{~cm})$ was observed in Samba Kooja. The petiole length $(2.55 \mathrm{~cm})$ was found to be minimum in Duraipandi (Table 2).The significant variation among the genotypes for leaf length and leaf width could be due to the genetic constitution of particular variety and interaction with environmental factors. This was supported by the findings of Samanta et al., (1999) who observed the broad range of variation for leaf length among the 25 types of mango grown in West Bengal. Majumder et al., (2011) and Joshi et al., (2013) also reported the significant variations in leaf width of mango.

\section{Flowering characteristics}

Significant differences were observed among the mango cultivars with respect to date and time of panicle emergence. The date of panicle emergence was found to be earliest in Malpacharisi (20 Nov-2 Jan) followed by Sendhuram (22 Nov -26 Dec), ArkaAruna (24 Nov-2 Jan) and Imam pasand (24 Nov-2 Jan ), while late emergence was observed in Komangai (17 Feb -9 Mar), Mallika (16 Feb 4 Mar) and Kuruvi Neelum (16 Feb -2 Mar).The variation observed in terms of panicle initiation might be due to the differences in genetic composition of parental mango genotypes. Singh (2003) and Kanpure et al., (2009) also observed variation in date of panicle emergence among the mango varieties. Phenology pattern is strongly under environmental control in mango. The vegetative cycle ceases with the advent of winter and maturation of the leaves takes place along with the dormancy of the apical and axillary buds. The plant remains visually dormant for about three months during winter. The reproductive flushes are also usually asynchronous in tropics. Synchronized flowering flushes, throughout the canopy in sub tropics, are primarily due to lower night temperature $\left(5-10{ }^{\circ} \mathrm{C}\right)$. In places of less night temperature $\left(10-18{ }^{\circ} \mathrm{C}\right)$ as in tropics, asynchronous reproductive flushes are common. Such delayed vegetative growth can reduce the potential for new shoots to flower during the next flowering season. The panicle length $(39.50 \mathrm{~cm})$ and width $(28.53 \mathrm{~cm})$ was observed maximum in Ratna. However, minimum panicle length $(17.52 \mathrm{~cm})$ and width (11.49 $\mathrm{cm})$ was recorded in Banganapalli and Iswarya respectively. The variation in size and shape of panicles in mango cultivars might be due to genetic composition and more specifically the physiological condition of the shoot on which panicle arise. These results are in agreement with the findings of Thimmappaiah and Suman (1987) in different mango cultivars and they found that panicle size varied from $11.00 \mathrm{~cm}$ to $42.00 \mathrm{~cm}$. Uthaiah et al., (1988), Yadav et al., (2010), Majumder et al., (2011) and Pawan and Chatterjee (2011) also reported variation in inflorescence length of different mango varieties. Narayanaswamy (1982) reported that the length and width of inflorescence in five varieties of mango ranged from $21.33 \mathrm{~cm}$ to $34.36 \mathrm{~cm}$ and 18.11 $\mathrm{cm}$ to $32.83 \mathrm{~cm}$, respectively (Table 3 ).

Flowers arealso borne on the older flushes of more than two years. The flowers dominate the terminals and if fruit are set, the vegetative growth does not occur from theses terminals until the crop is harvested. If the flowers fail to set the fruit or fruit drop occur prematurely, the terminals produce vegetative growth immediately. The maximum number of male flowers (1063.53) was observed significantly in Alphonso. However, minimum number of male flowers (528.47) was observed in Samba kooja. 
Table.1 Mean performance of mango genotypes for tree characters

\begin{tabular}{|c|c|c|c|c|}
\hline S.No. & Genotypes & $\begin{array}{l}\text { Tree height } \\
\text { (m) }\end{array}$ & $\begin{array}{l}\text { Stem girth } \\
\text { (cm) }\end{array}$ & $\begin{array}{c}\text { Tree spread (m) } \\
(\mathrm{EW}+\mathrm{NS} / 2)\end{array}$ \\
\hline 1 & Alphonso & $6.09 *$ & $62.67 *$ & $6.88 *$ \\
\hline 2 & Amarapali & $6.13 *$ & 50.87 & $6.88^{*}$ \\
\hline 3 & ArkaAruna & 5.67 & 53.00 & 5.95 \\
\hline 4 & ArkaPuneet & 4.62 & 42.27 & 6.50 \\
\hline 5 & Au Rumani & 4.50 & 36.33 & 5.25 \\
\hline 6 & Banganapalli & 5.46 & 34.13 & 5.74 \\
\hline 7 & Duraipandi & 7.76 & $63.67 *$ & 6.58 \\
\hline 8 & Imam Pasand & 4.78 & 46.97 & 5.34 \\
\hline 9 & Iswarya & 5.31 & $61.10^{*}$ & 6.10 \\
\hline 10 & Javari & 4.93 & 25.13 & 4.10 \\
\hline 11 & Komangai & 4.35 & 37.23 & 4.05 \\
\hline 12 & Kovankachi & 5.42 & 48.73 & 6.18 \\
\hline 13 & KundurPacharisi & 4.19 & 29.07 & 4.56 \\
\hline 14 & KuruviNeelum & 3.71 & 31.10 & 3.64 \\
\hline 15 & Mallika & 5.58 & 57.00 & 6.53 \\
\hline 16 & Malpacharisi & 4.90 & 36.33 & 5.46 \\
\hline 17 & Mohandhas & 4.19 & 32.37 & 4.28 \\
\hline 18 & NathamPalamani & 5.94 & $68.1 *$ & 7.76 \\
\hline 19 & Neelum & 5.30 & 43.53 & 6.42 \\
\hline 20 & P.K.Patti & 3.98 & 26.67 & 3.35 \\
\hline 21 & Pedharasam & 4.36 & 47.00 & 5.58 \\
\hline 22 & PKM 1 & $6.71 *$ & $78.53^{*}$ & 6.55 \\
\hline 23 & PKM 2 & 5.23 & 57.23 & 6.48 \\
\hline 24 & Ratna & 7.41 & $83.26^{*}$ & $8.44 *$ \\
\hline 25 & Samba Kooja & 3.57 & 33.23 & 3.6 \\
\hline 26 & Sendhuram & $6.28 *$ & $71^{*}$ & 7.67 \\
\hline 27 & Shajahan & 4.28 & 37.33 & 3.73 \\
\hline 28 & Sindhu & 5.33 & 49 & 6.12 \\
\hline 29 & Sothuparaivadumangai & 5.27 & 52.7 & 5.65 \\
\hline \multirow[t]{6}{*}{30} & SundarLangra & $8.36^{*}$ & $103.97 *$ & $8.99 *$ \\
\hline & Mean & 5.32 & 49.98 & 5.81 \\
\hline & $\mathrm{CD}$ at $5 \%$ & 0.69 & 9.46 & 0.91 \\
\hline & SE.m & 0.24 & 3.33 & 0.32 \\
\hline & SE.d & 0.34 & 4.71 & 0.45 \\
\hline & $\mathrm{CV}(\%)$ & 7.91 & 11.55 & 9.56 \\
\hline
\end{tabular}


Table.2 Mean performance of mango genotypes for leaf characters

\begin{tabular}{|c|c|c|c|c|}
\hline S.No. & Genotypes & $\begin{array}{l}\text { Leaf length } \\
(\mathrm{cm})\end{array}$ & $\begin{array}{l}\text { Leaf width } \\
(\mathrm{cm})\end{array}$ & $\begin{array}{l}\text { Petiole length } \\
(\mathbf{c m})\end{array}$ \\
\hline 1 & Alphonso & $32.85 *$ & 7.01 & $5.82 *$ \\
\hline 2 & Amarapali & $28.97 *$ & 6.76 & 3.85 \\
\hline 3 & ArkaAruna & $30.51^{*}$ & 7.27 & $6.28 *$ \\
\hline 4 & ArkaPuneet & 19.41 & 7.60 & 3.67 \\
\hline 5 & Au Rumani & 17.47 & 4.90 & 3.00 \\
\hline 6 & Banganapalli & 24.19 & 5.77 & 4.60 \\
\hline 7 & Duraipandi & 18.65 & 4.80 & 2.55 \\
\hline 8 & Imam Pasand & 22.69 & 8.11 & 4.16 \\
\hline 9 & Iswarya & $28.87 *$ & 6.93 & $5.33 *$ \\
\hline 10 & Javari & 19.58 & 4.91 & 2.70 \\
\hline 11 & Komangai & 23.17 & 6.39 & 3.58 \\
\hline 12 & Kovankachi & 20.28 & 4.80 & 2.89 \\
\hline 13 & KundurPacharisi & $25.84 *$ & 6.12 & $4.97 *$ \\
\hline 14 & KuruviNeelum & 21.89 & 4.09 & 3.23 \\
\hline 15 & Mallika & $27.41 *$ & 6.97 & $4.92 *$ \\
\hline 16 & Malpacharisi & 20.20 & 5.91 & 3.48 \\
\hline 17 & Mohandhas & 23.34 & 4.49 & 3.93 \\
\hline 18 & NathamPalamani & $25.87 *$ & 6.69 & 3.05 \\
\hline 19 & Neelum & 22.89 & 6.14 & 3.92 \\
\hline 20 & P.K.Patti & 18.10 & 5.74 & 3.06 \\
\hline 21 & Pedharasam & 21.19 & 5.17 & 3.04 \\
\hline 22 & PKM 1 & $25.79 *$ & 6.34 & 3.75 \\
\hline 23 & PKM 2 & 24.33 & 5.70 & 4.23 \\
\hline 24 & Ratna & $25.37 *$ & 6.33 & $4.67 *$ \\
\hline 25 & Samba Kooja & 15.88 & 2.64 & 2.88 \\
\hline 26 & Sendhuram & 22.65 & 6.05 & 2.64 \\
\hline 27 & Shajahan & 16.52 & 5.32 & 3.96 \\
\hline 28 & Sindhu & $26.40 *$ & $10.24 *$ & $5.55^{*}$ \\
\hline 29 & Sothuparaivadumangai & 18.49 & 4.53 & 2.60 \\
\hline \multirow[t]{6}{*}{30} & SundarLangra & 22.79 & 5.77 & 3.64 \\
\hline & Mean & 23.05 & 5.98 & 3.87 \\
\hline & $\mathrm{CD}$ at $5 \%$ & 1.82 & 2.47 & 0.79 \\
\hline & SE.m & 0.64 & 0.87 & 0.28 \\
\hline & SE.d & 0.91 & 1.23 & 0.39 \\
\hline & $\mathrm{CV}(\%)$ & 4.77 & 14.89 & 13.19 \\
\hline
\end{tabular}

$*_{\text {-Significant at } 5 \%}$ 
Table.3 Mean performance of mango genotypes for inflorescence characters

\begin{tabular}{|c|c|c|c|c|c|c|c|c|}
\hline S.No. & Genotypes & $\begin{array}{l}\text { Date of } \\
\text { flower } \\
\text { opening }\end{array}$ & $\begin{array}{l}\text { Panicle } \\
\text { length } \\
(\mathrm{cm})\end{array}$ & $\begin{array}{c}\text { Panicle } \\
\text { width }(\mathrm{cm})\end{array}$ & $\begin{array}{c}\text { No. of male } \\
\text { flowers/panicle }\end{array}$ & $\begin{array}{c}\text { No. of } \\
\text { perfect } \\
\text { flowers/ } \\
\text { panicle }\end{array}$ & $\begin{array}{c}\text { Perfect } \\
\text { flower } \\
\%\end{array}$ & $\begin{array}{c}\text { Sex ratio } \\
\text { (perfect to } \\
\text { male) }\end{array}$ \\
\hline 1 & Alphonso & 27.12.17 & 20.06 & 11.69 & $1063.53 *$ & 207 & 16.29 & $1: 5.1 *$ \\
\hline 2 & Amarapali & 13.2 .18 & 31.36 & $21.25 *$ & $942.60 *$ & 242.87 & 20.49 & $1: 3.9^{*}$ \\
\hline 3 & ArkaAruna & 24.11.17 & 21.1 & 14.29 & 640 & 203.87 & $24.16^{*}$ & 01:03.1 \\
\hline 4 & ArkaPuneet & 20.12.17 & 20.21 & 11.95 & 642.8 & 164.33 & 20.36 & $1: 3.9^{*}$ \\
\hline 5 & Au Rumani & 1.12 .17 & 20.79 & 15.44 & 661.87 & 219.2 & $24.88^{*}$ & 01:03.0 \\
\hline 6 & Banganapalli & 16.2.18 & 17.52 & 13.35 & 550.67 & 190.73 & $25.73^{*}$ & 01:02.9 \\
\hline 7 & Duraipandi & 15.2.18 & 21.87 & 12.96 & 818.4 & 267.87 & $24.66^{*}$ & 01:03.1 \\
\hline 8 & Imam Pasand & 24.11 .17 & 20.35 & 12.85 & 704.8 & 167 & 19.16 & $1: 4.2 *$ \\
\hline 9 & Iswarya & 15.2.18 & 25.72 & 11.49 & 677.6 & 196.33 & 22.47 & $01: 03.5$ \\
\hline 10 & Javari & 15.2 .18 & 23.86 & 14.63 & $904.00^{*}$ & 249.4 & 21.62 & 01:03.6 \\
\hline 11 & Komangai & 17.2.18 & 25.88 & 15.92 & 589.13 & 219.6 & $27.15^{*}$ & 01:02.7 \\
\hline 12 & Kovankachi & 28.1.18 & 27.77 & 12.78 & $978.73 *$ & $281.53^{*}$ & 22.34 & 01:03.5 \\
\hline 13 & KundurPacharisi & 25.12 .17 & 26.44 & $20.85^{*}$ & $935.47^{*}$ & $340.67^{*}$ & $26.70 *$ & $01: 02.8$ \\
\hline 14 & KuruviNeelum & 16.2.18 & 20.37 & 12.69 & 554.73 & 244.53 & $30.59 *$ & 01:02.3 \\
\hline 15 & Mallika & 16.2.18 & 29.81 & $22.49 *$ & 782.33 & $335.07 *$ & $29.99 *$ & $01: 02.3$ \\
\hline 16 & Malpacharisi & 20.11 .17 & 22.85 & 17.19 & 815.67 & $283.20^{*}$ & $25.77 *$ & 01:02.9 \\
\hline 17 & Mohandhas & 13.12.17 & 24.85 & 12.97 & 641 & 192.73 & 23.12 & 01:03.3 \\
\hline 18 & NathamPalamani & 15.2 .18 & 23.07 & 13.09 & 857.07 & 205.07 & 19.31 & $1: 4.2 *$ \\
\hline 19 & Neelum & 13.2.18 & 27.27 & 18.53 & $908.13^{*}$ & 192.47 & 17.49 & $1: 4.7^{*}$ \\
\hline 20 & P.K.Patti & 12.12.17 & 25.36 & 12.84 & 797.33 & 262.53 & $24.77 *$ & 01:03.0 \\
\hline 21 & Pedharasam & 13.12.17 & 32.94 & 13.33 & $1021^{*}$ & $325.80^{*}$ & $24.19 *$ & 01:03.1 \\
\hline 22 & PKM 1 & 10.2 .18 & 33.89 & $20.71 *$ & $964.47 *$ & 177.6 & 15.55 & $1: 5.4^{*}$ \\
\hline 23 & PKM 2 & 6.12 .17 & 28.08 & $20.74 *$ & 581.33 & 187.27 & $24.36^{*}$ & 01:03.1 \\
\hline 24 & Ratna & 15.12.17 & $39.50 *$ & $28.53^{*}$ & 995.8 & $338.67 *$ & $25.38^{*}$ & 01:02.9 \\
\hline 25 & Samba Kooja & 5.2 .18 & 22.79 & 12.77 & 528.47 & 171.53 & $24.50 *$ & 01:03.1 \\
\hline 26 & Sendhuram & 22.11 .17 & 26.13 & $19.06^{*}$ & 820.8 & 214.07 & 20.69 & 01:03.8 \\
\hline 27 & Shajahan & 15.2 .18 & 25.73 & 13.81 & 644.93 & 150.73 & 18.94 & $1: 4.3^{*}$ \\
\hline 28 & Sindhu & 13.2.18 & 26.43 & $19.37 *$ & 1046.13* & $285.60^{*}$ & 21.45 & $1: 3.7^{*}$ \\
\hline 29 & $\begin{array}{l}\text { Sothuparaivaduma } \\
\text { ngai }\end{array}$ & 11.2 .18 & 21.9 & 16.15 & 617.27 & $282.93 *$ & $31.43 *$ & 01:02.2 \\
\hline \multirow[t]{6}{*}{30} & SundarLangra & 10.2 .18 & 25.14 & 14.63 & $957.13^{*}$ & 230.27 & 19.39 & $1: 4.2^{*}$ \\
\hline & Mean & & 25.3 & 15.94 & 788.11 & 234.35 & 23.1 & $01: 03.5$ \\
\hline & $\mathrm{CD}$ at $5 \%$ & & 8.77 & 2.92 & 82.33 & 36.8 & 0.97 & 0.15 \\
\hline & SE.m & & 3.09 & 1.03 & 29.01 & 12.97 & 0.34 & 0.05 \\
\hline & SE.d & & 4.37 & 1.46 & 41.02 & 18.34 & 0.48 & 0.08 \\
\hline & CV (\%) & & 8.18 & 8.54 & 6.38 & 9.58 & 2.57 & 2.64 \\
\hline
\end{tabular}

$*_{-}$Significant at $5 \%$ 
In conclusion, there were distinct variations for different vegetative and flowering characters among mango cultivars under study. On the basis of results obtained it may be concluded that the genotypes like SundarLangra, ArkaAruna, Sendhuram and Alphonso were superior in most of the characters. The information generated from this study will be useful for various stakeholders like breeders for improvement of varieties by selecting the suitable parental material, food processors by selecting the varieties with suitable nutritional value, etc. This research work can be further validated by evaluating these varieties with suitable molecular markers.

\section{Acknowledgement}

The authors thank the Department of Fruit Crops, Horticultural College and Research Institute for providing the technical and Management support.

\section{References}

Afifi, M. M. G., A. D. Shaltout, M. A. Nasar, R. B. Mohamed and I. M. Desouky. 2000. Annals of Agric. Sci., 18: 12451257.

APEDA Agri exchange (2016-17), Ministry of commerce and Industry, Govt of India.

Chanana, Y. R., J. S. Josan and P. K. Arora. 2005. Evaluation of some mango cultivars under North Indian conditions. In Proceedings: International conference on mango and date palm: Culture and Export. pp. 36-40.

India stat (2016-17), Minister of state, Dept. of statistics, Planning and Public Grievances, Govt. of India.

Joshi, R., M. Kundu and C. P. Singh. 2013. Morphological Characters: Efficient Tool for identification on different mango cultivars. Environment and
Ecology., 31(1A): 385- 388.

Kanpure, R.N., H. P. Singh and R. K. Reja. 2009. Evaluation of mango hybrids for Kymore Plateau of Madhya Pradesh. Journal Community Mobilization and Sustainable Development., 4(2): 1-3.

Majumder, D. A. N., L. Hassan, M. A. Rahim and M. A. Kabir. 2011. Studies on physic morphology, floral biology and fruit characteristics of mango. J. Bangladesh Agric. Univ., 9(2): 187-199.

Mukherjee, S. K. 1997. Introduction: Botany and importance. In: The mango Botany, Production and Uses 1 st edition $(R$. E. Litz Ed.), CAB International, Wallingford, UK. pp. 1-19.

Narayanaswamy, P. 1982. Studies on blossoms biology, sex ratio and fruit set in certain cultivars of mango. M.Sc. (Hort.) thesis, University of Agricultural Sciences, Banglore, India. 95p.

Pawan, K. T. S. and D. Chatterjee. 2011. Evaluation of some colored mango varieties for their flowering, fruiting and fruit quality attributes. J. Inter academicia., 15(3): 382-387.

Rymbai, H., M. Srivastav, R. R. Sharma and S. K. Singh. 2012. Lenticels on mango fruit: origin, development, discoloration and prevention of their discoloration. Scientia Hortic., 135: 164-170.

Samanta, A. K., T. Chatopadhyay and S. Roy. 1999. Genetic variability of some fruit characters in mango (Mangifera indica L.). Environment and Ecology., 17(2): 488-490.

Singh, R. K., S. K. Singh, R. K. Ojha and C. Singh. 2009. Flowering and fruiting behaviour of different mango cultivars under Jharkhand condition. Environment and Ecology, 27(4B): 213-215.

Singh, S. 2003. Evaluation of mango genotypes for their flowering, fruiting and fruit quality attributes. Annals of Agric. Res., 24(2): 234-238. 
Srivastava, S.S., K. P. Asata, M.P. Patel, B. L. Tiwary and U. P. S. Bhadauria. 1987. Evaluation of mango varieties in Madhya Pradesh. Indian J. Hortic., 44(3-4): 197-201.

Thimmappaiah, C. L. and D. Suman. 1987. Sex in relation to fruit set and fruit yield in mango. Punjab Horticultural Journal., 27: 8-11.

Uthaiah, B. C., K. M. Indiresh, I. S. A.
Hussain, K. B. Rao and H. Hanummaiah. 1988. Flower and sex variation in mango varieties under coastal Karnataka. Progressive Hortic., 20: $120-123$.

Yadav, P., O. P. Chaturvedi, D. Yadav and H. C. Yadav. 2010. Studies the vegetative growth, flowering and fruiting behaviour of promising cultivars of mango. Plant Archives., 10(1): 453-455.

\section{How to cite this article:}

Indian, G., Eslavathkhamdar Naik, M. Deenavarman, K. Jagathesan and Janani, T. 2020. Studies on the Growth and Flowering Behavior of Different Mango (Mangifera indica L.) Genotypes. Int.J.Curr.Microbiol.App.Sci. 9(06): 1981-1989.

doi: https://doi.org/10.20546/ijcmas.2020.906.244 